\title{
Developing Early Childhood Cognitive Aspects Based on Anderson And Krathwohl's Taxonomy
}

\author{
Dek Ngurah Laba Laksana1, Konstantinus Dua Dhiu², Maxima Yohana Jau³, \\ Melania Restintuta Ngonu ${ }^{4}$ \\ ${ }^{1}$ Elementary Teacher Education Department, STKIP Citra Bakti, Bajawa \\ 2,3,4Early Childhood Teacher Education Department, STKIP Citra Bakti, Bajawa \\ email: laba.laksana@citrabakti.ac.id ${ }^{1}$, konstantinusdua@citrabakti.ac.id², maximajau16@citrabakti.ac.id ${ }^{3}$, \\ restinngonu96@citrabakti.ac.id ${ }^{4}$
}

\begin{abstract}
Developing cognitive learning objectives becomes prior needs to be prepared by teachers. The aspect of early childhood education includes language development, physical-motor, cognitive, socioemotional, religious-morality, and art. The development of cognitive aspects becomes very important in efforts to develop lesson planning, learning materials, and assessment. This study aims to produce instructional media on cognitive aspects that are appropriate to the characteristics of early childhood education. The instructional media was developed using the research and development design with Rowntree model. The Rowntree development model consists of 3 phases, those are planning phase, development phase, and the evaluation phase. The study was conducted involving 10 early childhood education institutions in Ngada Regency, East Nusa Tenggara, Indonesia. Data was collected by documenting the learning process and utilizing rubrics for assessing the development of cognitive domain. The data were analyzed using descriptive analysis to describe the quality of the products on cognitive domain in early childhood education. The results showed that the development of cognitive aspects in early childhood learning consisted of three aspects, namely aspects of learning and problem solving, aspects of logical thinking, and aspects of symbolic thinking. The development of cognitive aspects in early childhood education for children aged 5-6 years based on Anderson and Krathwohl's Taxonomy produced 18 learning objectives. On the other hand, the development of cognitive aspects in early childhood education aged 4-5 years based on the taxonomy of Anderson and Krathwohl produced 15 learning objectives. The learning objectives of the results of the development had been examined by instructional content experts, instructional design experts, and product user. The test results in the cognitive aspects of learning objectives are in the "very good" category.
\end{abstract}

Keywords: cognitive domain, early childhood, Anderson dan Krathwohl's taxonomy

\section{Introduction}

Education comprises several specific aspects namely pedagogy, andragogy, curriculum, instructions, educational policy, organization and leadership (Webb, Metha, \& Jordan, 2010). Further, education as stated in Indonesia Constitution No.20 in 2003 is defined as a conscious and planned act to create an atmosphere of learning and instructional process which leads students to actively develop their potential on spiritualism, self-control, personality, intelligence, noble character, and the skills needed by themselves, society, and nation. Thus, the curriculum and constructed efforts implemented in learning are important things to develop.

Instructions is a process of guiding individuals to develop by adjusting to their level (Bransford, Brown, \& Cocking, 2000). The level of development includes the individual needs of life, social, and as God's creation (Kemendikbud, 2014). Therefore, instructional process fosters individual to experience a change in behavior based on their level (Arend, 2013). The level of children development varies from birth to adult. It depends on the physical condition, genetic, and environment (Laksana, 2017). The level of children development covers cognition, motoric, sensory, physic, language, and emotion (Kemendikbud, 2014; Krogh \& Morehouase, 2014; Krogh \& Slentz, 2010). Piaget \& Inhelder (2019) state that the early children cognitive development includes sensory-motor and pre-operational stage. 
Early childhood education is the implementation of educational process that focuses on laying the foundation for physical, intellectual, socio-emotional, cognitive growth, arts and language (Kemendikbud, 2014). On the other hand, in the Indonesia constitution No. 20, 2003, early childhood education is defined as any effort to train children from the moment they were born to the age of six through the provision of educational stimuli to help physical and spiritual growth and development so that children have readiness to enter further education. Furthermore, Arends (2013; Laksana, 2017; Muga, Oje \& Laksana, 2018) argue that learning and instructions are the various instructional activities that involve teacher and students to achieve learning goals. The achievement of the learning objectives should still pay attention to the three domains of student ability, namely cognitive, affective, and psychomotor (Hoque, 2017). The cognitive domain focuses on the children's thinking and reasoning skills. Whereas the affective domain focuses on children's attitudes. Lastly, the psychomotor domain focuses on children's hard skills (Hoque, 2017; Selmi, Gallagher, and Mora-Flores, 2014). One of the three abilities is the cognitive aspect. Cognitive aspect is related to knowledge, reasoning, and thinking skill (Anderson \& Krathwohl, 2001; Tomar and Kumari, 2017).

Instructional process is not only a matter of series of activities, but also assessment. One of the basic principles that must be considered and held in assessment is the whole principle. Assessment of learning achievement must include three aspects, namely cognitive (understanding of the materials), affective (attitude), and psychomotor (skills) (Hoque, 2017). These three aspects are closely related and cannot be separated from the learning assessment activities. Furthermore, Anderson \& Krathwohl (2001) asserted that a professional teacher must formulate learning objectives in the form of observable changes in students' behavior after learning. This is also supported by research conducted by Pertiwi, Arini, \& Widiana (2016) which shows that the assessment of cognitive aspects by teachers is still limited to the aspect of remembering.

In fact, there are still many problems of early childhood education system. Various problems are found in the development of early childhood learning objectives. One of the problems is the content of learning on the cognitive aspect is not in accordance with the existing learning objectives (Novitasari, 2018; Winarni, 2017). This finding is in line with the results of the analysis conducted by researchers, which found that the instructional media used by teachers are not in accordance with the theory of early childhood cognitive development. this particular media shows an error in determining the learning objectives. The details of the problems are presented as follow: learning objectives which should be stated in the cognitive aspects are placed on other aspects. This needs to be corrected since mistakes in formulating learning objectives have an impact on errors in constructing instructional media, learning activities, and evaluation (laksana, 2017). Another problem is displayed by Pertiwi, Arini, \& Widana (2016) who assert that the evaluation from teachers is limited to the students' memorizing ability. This level of cognitive has not been able to encourage children creative thinking and further lead to children's cognitive development.

Thus, cognitive aspect of early childhood is one that needs to be developed. By using cognitive abilities, children can solve problems in daily life. In addition, the development of cognitive aspects of early childhood foster children to think logically, even think abstractly (Kemendikbud, 2014). This is also confirmed by the findings of Widiana \& Jampel (2017) who find out that cognitive ability and multiple intelligences are closely related to creative thinking skills.

Based on the aforementioned explanation, the problems examined are formulated as follows. (1) How are the results of developing cognitive learning objectives that referring to Anderson and Krathwolh's theory in the 2013 Curriculum for early childhood education? And (2) How is the quality of the product as a result of developing cognitive learning objectives based on Anderson and Krathwolh's theory in the 2013 Curriculum for early childhood education?

\section{Method}

This study employs research and development design. The development model used is the Rowntree model consisting of 3 stages, namely planning, development, and evaluation 
stage. The planning stage is the analysis of the learning objectives that have been used by teachers in early childhood learning in accordance with the 2013 curriculum (Kemendikbud, 2014). This stage also focuses on error analysis of the learning objectives in the cognitive domain as well as analysis of annual programs, semester programs, weekly programs and daily programs. At the development stage, cognitive aspects are arranged based on the findings and analysis that have been carried out at the planning stage. This process is continued by developing the cognitive learning objectives that can be used for early childhood education based on the aforementioned theories. In the evaluation stage, the researcher utilized the formative evaluation model. This was used to reveal the quality of the products developed. The quality of the product itself was examined from three different perspectives namely instructional content expert, instructional design expert, and field try out of the developed products. Product evaluations were carried out by instructional content expert who had experience in early childhood learning. On the other hand, instructional design expert test is conducted by expert who had expertise in learning technology. While testing for product users, in this case nursery teachers, was conducted on teachers who had experience in early childhood education.

Data collection methods used can be explained as follows. (1) The data regarding the needs for learning resources were collected through 2013 PAUD curriculum analysis on its learning objectives. (2) Data regarding the construction of learning objectives on the cognitive aspects of the two schools can be seen from the content, presentation, and language. These three were obtained from the analysis of learning objectives on cognitive aspects in the learning process. The data were collected using questionnaires, interview, observation, and documentation. The collected data were then analyzed descriptively to illustrate the quality of the cognitive aspects of the instructional media based on Anderson and Krathwohl's theory.

\section{Results}

The results of the development of cognitive aspects in early childhood education consist of 3 aspects, namely aspects of learning and problem solving, aspects of logical thinking, and aspects of symbolic thinking. Each of these aspects had been developed into several learning objectives. The results of the development of learning objectives on cognitive aspects based on Anderson and Krathwolh's Taxonomy in children aged 4-5 years and 5-6 years are presented in Table 1 and Table 2.

The development of cognitive learning objectives based on Anderson and Krathwolh's Taxonomy is organized into four main sections as follows: 1) annual programs, 2) semester programs, 3) weekly learning implementation plans, and 4) daily learning implementation plans. The learning objectives of cognitive aspects based on Anderson and Krathwolh's Taxonomy developed in this study, have been revised based on expert validation.

Instructional content expert validation provides an assessment of the products that are developed in the excellent category. Furthermore, the validation from instructional design expert provides an assessment of the products being developed in the excellent category. The emphasis of assessment is on the aspect of suitability of the instructional media used with the learning objectives developed, and organizing the material from concrete to abstract. The results of the instructional content expert validation, instructional design and test on product users are presented in Table 3, Table 4, and Table 5. 
Table 1. Results of the development of cognitive aspects in early childhood education at 5-6 years old based on Anderson and Krathwohl's taxonomy

\begin{tabular}{|c|c|c|}
\hline No & Cognitive Aspect & Description of Cognitive Learning Objectives \\
\hline 1 & $\begin{array}{l}\text { Learning and problem } \\
\text { solving }\end{array}$ & $\begin{array}{l}\text { 1. Students are able to say the activities they do through } \\
\text { experiment with rocks and papers in a container filled with } \\
\text { water }\end{array}$ \\
\hline 2 & Logical thinking & $\begin{array}{l}\text { 5. Students are able to recall things based on its size } \\
\text { 6. Students are able to arrange blocks through games } \\
\text { 7. Students are able to predict a cause and effect relationship } \\
\text { through observation } \\
\text { 8. Students are able to match things based on its color, shape, } \\
\text { and size through games } \\
\text { 9. Students are able to arrange more blocks through games } \\
\text { 10. Students are able to distinguish the pattern of ABCD } \\
\text { 11. Students are able to match the numbers with pictures } \\
\text { through several activities } \\
\text { 12. Students are able to arrange the number from } 1-10 \text { through } \\
\text { games } \\
\text { 13. students are able to appreciate art and paint from the little } \\
\text { thing to a bigger one } \\
\text { 14. Students are able to distinguish materials based on its } \\
\text { shape }\end{array}$ \\
\hline 3 & Symbolic thinking & $\begin{array}{l}\text { 15. Students are able to count numbers from one to ten through } \\
\text { games } \\
\text { 16. Students are able to distinguish vowel symbols thorugh } \\
\text { question and answer } \\
\text { 17. Students are able to distinguish consonant symbol through } \\
\text { question and answer }\end{array}$ \\
\hline
\end{tabular}

Meanwhile, the cognitive learning objectives based on Anderson and Krathwolh's taxonomy for children aged of 4-5 years old can be presented as follows:

Table 2. Results of the development of cognitive aspects in early childhood education at 4-5 years old based on Anderson and Krathwohl's taxonomy

\begin{tabular}{cll}
\hline No & Cognitive aspects & Description of Cognitive Learning Objectives \\
\hline 1 & $\begin{array}{l}\text { Learning and problem } \\
\text { solving }\end{array}$ & 1. $\begin{array}{l}\text { Students are able to arrange blocks based on its function } \\
\text { such as pencil to write through games }\end{array}$ \\
& 2. Students are able to arrange symbolic blocks such as playing \\
car toys
\end{tabular}




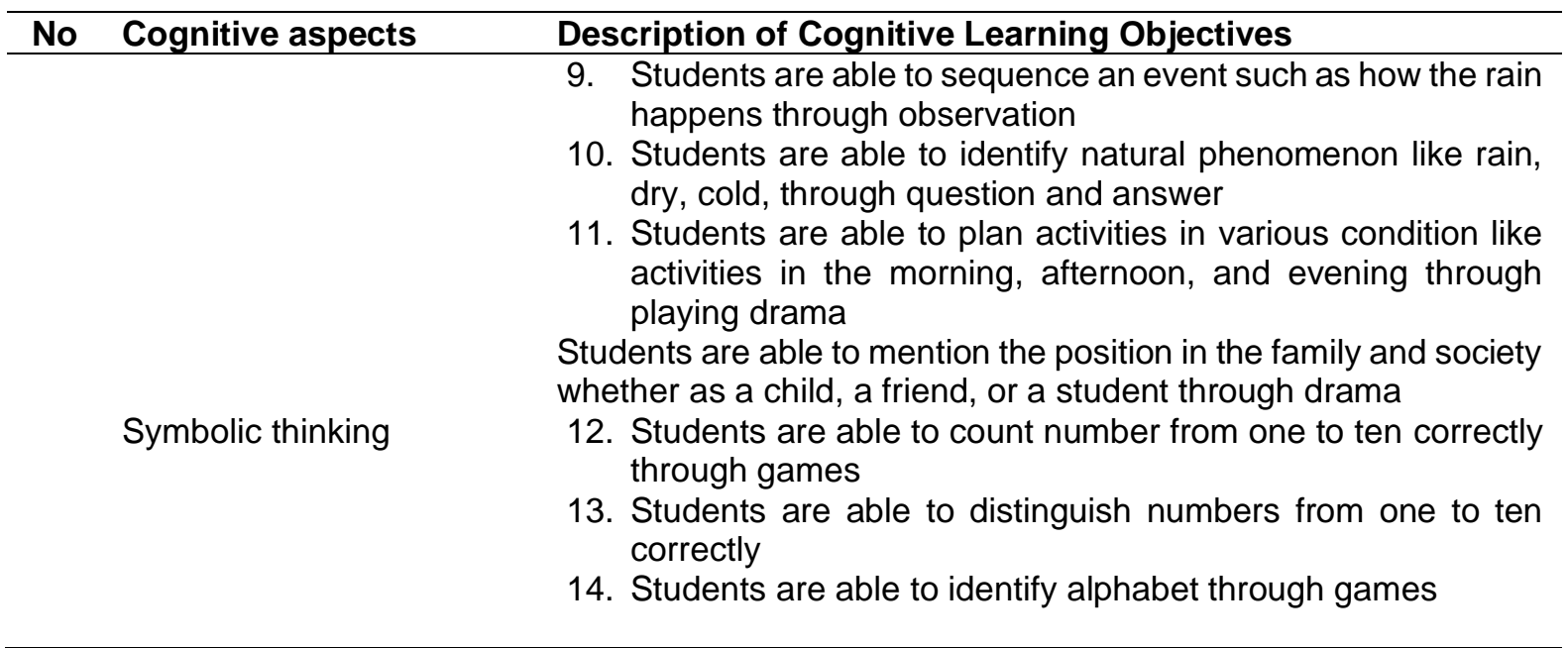

The validation on the instructional content to the expert of it covers twelve indicators. These twelve indicators ranges from the categories of "good" and "very good".

Specifically, there were 10 indicators that were assessed as "very good". These 10 indicators include: the suitability of the learning objectives to the core competence; suitability of the learning objectives to the indicators of learning achievement; suitability of the learning objectives to the learning materials; suitability of the learning objectives to the methods and techniques; suitability of the learning objectives to the instructional procedure; suitability of the learning objectives to the organization of the learning objectives from concrete to abstract; suitability of the learning objectives to the children cognitive development level based on Anderson and Krathwolh; suitability of the learning objectives that contains operational terms to the Anderson and Krathwolh taxonomy.

On the other hand, there were two "good" indicators. These indicators are: the suitability of the learning objectives to the assessment used as well as the purpose of the development of learning objectives based on ABCD theory (audience, behavior, condition, and degree). The details are presented in Table 3.

Table 3. Experts test results on instructional content and learning devices based on Anderson and Krathwohl's taxonomy

\begin{tabular}{|c|c|c|}
\hline No & Aspects & Category \\
\hline 1 & Suitability of the learning objectives to the core competence & Very good \\
\hline 2 & Suitability of the learning objectives to the learning indicators & Very good \\
\hline 3 & Suitability of the learning objectives to the learning materials & Very Good \\
\hline 4 & Suitability of the learning objectives to the teaching methods & Very good \\
\hline 5 & Suitability of the learning objectives to the instructional procedure & Very good \\
\hline 6 & Suitability of the learning objectives to the assessment & Good \\
\hline 7 & $\begin{array}{l}\text { Suitability of the learning objective to the ABCD theory (Audience, } \\
\text { Behavior, Condition, Degree) }\end{array}$ & Good \\
\hline 8 & $\begin{array}{l}\text { Suitability of the learning objectives to the students proximal } \\
\text { development }\end{array}$ & Very good \\
\hline $\begin{array}{c}9 \\
10\end{array}$ & $\begin{array}{l}\text { Organization of the learning objectives from simple to complex } \\
\text { Organization of the learning objectives from concrete to abstract }\end{array}$ & $\begin{array}{l}\text { Very good } \\
\text { Very good }\end{array}$ \\
\hline 11 & $\begin{array}{l}\text { Suitability of the learning objectives to the cognitive level based on } \\
\text { Anderson and Krathwol theory }\end{array}$ & Very good \\
\hline 12 & $\begin{array}{l}\text { The learning objectives have operational terms that suits to Anderson } \\
\text { and Krathwol taxonomy }\end{array}$ & Very good \\
\hline
\end{tabular}

The test on the instructional media to the expert consists of 10 indicators. These 10 indicators vary from the "good" to the "very good" category.

There were six indicators that were categorized as "very good". These six indicators are: completeness of the component of instructional design (core competence, basic competence, 
indicators, learning objectives, learning material, assessment); the accuracy of the learning objectives formulation that refer to operational terms; suitability of the materials to the learning objectives; suitability of the assessment to the learning objectives; suitability of the instructional procedure to the level of early childhood learning development; and serving systematic consistency in learning activities.

Meanwhile, four indicators received "good" ratings. The four indicators include: the appropriateness of the learning media used with the learning objectives developed; appropriateness of learning material, sample questions, and practice questions with the level of early childhood learning development; organizing material from simple to complex; and organizing material from concrete to abstract. The details of the result are presented in Table 4.

Table 4. Expert Test Result in Instructional Design Based on Anderson And Krathwol's Taxonomy

\begin{tabular}{clc}
\hline No & \multicolumn{1}{c}{ Aspects } & Category \\
\hline 1 & $\begin{array}{l}\text { Completeness of the instructional design components } \\
\text { the accuracy of the learning objectives formulation that refer to }\end{array}$ & $\begin{array}{c}\text { Very good } \\
\text { Very good }\end{array}$ \\
2 & $\begin{array}{l}\text { operational terms } \\
\text { the appropriateness of the learning media used with the learning }\end{array}$ & Good \\
3 & objectives developed & Very good \\
4 & suitability of the materials to the learning objectives & Very good \\
5 & suitability of the assessment to the learning objectives & Good \\
6 & appropriateness of learning material, sample questions, and practice & questions with the level of early childhood learning development \\
7 & suitability of the instructional procedure to the level of early childhood & Very Good \\
8 & learning development & Good \\
9 & organizing material from simple to complex & Good \\
10 & serving systematic consistency in learning activities & Very good \\
\hline
\end{tabular}

Nevertheless, the field test of the product users of the instructional media covers 13 indicators. These 13 indicators were rated as "very good"

The indicators that had been rated as very good can be seen as follows: completeness of the instructional media; completeness of instructional design components; the accuracy of the formulation of learning objectives refers to basic competencies; the accuracy of the formulation of learning objectives refers to operational verbs; the suitability of the instructional media used with the learning objectives developed; the suitability of the material with the learning objectives; appropriateness of assessment with learning objectives; appropriateness of learning material with the level of early childhood learning development; appropriateness of learning activities with the level of early childhood learning development; appropriateness of instructional procedure with the level of early childhood learning development; organizing material from simple to complex; organizing material from concrete to abstract; and the consistency of systematic presentation in the instructional media. The details are presented in table 5.

Table 5. Product Users Test Results On The Instructional Media Based On Anderson And Krathwol's Taxonomy

\begin{tabular}{|c|c|c|}
\hline No & Aspects & Category \\
\hline 1 & $\begin{array}{l}\text { completeness of the instructional media (annual program, semester } \\
\text { program, weekly lesson plan, daily lesson plan) } \\
\text { completeness of instructional design components (Core competence, }\end{array}$ & Very good \\
\hline 2 & $\begin{array}{l}\text { basic competencies, learning indicators, learning objectives, learning } \\
\text { materials, and assessment) }\end{array}$ & Very Good \\
\hline 3 & $\begin{array}{l}\text { the accuracy of the formulation of learning objectives refers to basic } \\
\text { competencies }\end{array}$ & Very Good \\
\hline
\end{tabular}




\begin{tabular}{|c|c|c|}
\hline No & Aspects & Category \\
\hline 4 & $\begin{array}{l}\text { the accuracy of the formulation of learning objectives refers to } \\
\text { operational verbs }\end{array}$ & Very Good \\
\hline 5 & $\begin{array}{l}\text { the suitability of the instructional media used with the learning } \\
\text { objectives developed }\end{array}$ & Very Good \\
\hline 6 & the suitability of the material with the learning objectives & Very Good \\
\hline 7 & appropriateness of assessment with learning objectives & Very Good \\
\hline 8 & $\begin{array}{l}\text { appropriateness of learning material with the level of early childhood } \\
\text { learning development }\end{array}$ & Very Good \\
\hline 9 & $\begin{array}{l}\text { appropriateness of learning activities with the level of early childhood } \\
\text { learning development }\end{array}$ & Very Good \\
\hline 10 & $\begin{array}{l}\text { appropriateness of instructional procedure with the level of early } \\
\text { childhood learning development }\end{array}$ & Very Good \\
\hline 11 & organizing material from simple to complex & Very Good \\
\hline 12 & organizing material from concrete to abstract & Very Good \\
\hline 13 & the consistency of systematic presentation in the instructional media & Very Good \\
\hline
\end{tabular}

The teacher's perception of the instructional media developed is in the very good category. The device developed has met the standard level of children's learning achievement on cognitive aspects. Development of learning objectives on cognitive aspects based on Anderson and Krathwolh's Taxonomy can also facilitate early childhood education teachers in formulating learning objectives. From the learning objectives that have been prepared, the teacher can find out the level of cognitive development of children based on their cognitive levels. This perception is in line with Effendi (2017) who states that the use of Bloom's revision taxonomy by Anderson and Krathwolh in studying concepts and implementation in learning is a level of identifying students' skills from the basic level to the highest level.

The cognitive learning objectives in children age 4-5 and age 5-6, based on the taxonomy of Anderson and Krathwohl contains operational verbs. The use of operational verbs makes it easy for teachers to develop teaching materials, instructional media, and assess learning achievement (Hoque, 2017, Kemendikbud, 2014). Moreover, the sentences used in developing learning objectives are simple sentences, making it easier for teachers to translate them in the learning implementation plan. This is proven by the test conducted to nursery teachers that shows the results were in the excellent category.

According to Anderson and Krathwohl (2001) the levels of cognitive process of learning objectives are hierarchical, which means that the categories of cognitive process dimensions are arranged based on their level of complexity. The level of "understanding" is more complex than "remembering", "applying" is more complex than "understanding", and so on. The results of the development of cognitive learning objectives can facilitate educators in preparing lesson plans.

In addition, the results of the development of learning objectives using Anderson and Krathwolh's taxonomy can be used in accordance with the level of children development at the lowest level to the highest level. The learning objectives are developed using Anderson and Krathwohl's taxonomic operational verbs. The use of operational verbs makes it easy for educators to understand, organize, and implement learning objectives. Studies on cognitive aspects had been carried out by many previous researchers (Carson, Hunter, Kuzik et al. (2015; Zeng, Ayyub, Sun et al., 2017). The findings from Sarjono (2017) suggested that the development of questions using Bloom's Taxonomy that was revised by Anderson and Krathwolh can help teachers in compiling cognitive dimensions and learning achievement.

In line with these findings, Wahyuni (2017) revealed that the development of Anderson and Krathwolh's Taxonomy on thinking skills could be used to determine the extent of students' thinking skills in solving problems. Meanwhile, Pancaningrum (2016; Filtri \& Sembiring, 2018) suggested that the categories of knowledge, analysis, synthesis, and evaluation domains were very well provided with certain learning strategies. Furthermore, in these findings, students at the early childhood level could build their vocabulary and mindset (Rohmah \& Waluyo, 2014).

Additionally, research on cognitive and its impact on the ability to think creatively showed that cognitive aspects needed to be developed. This development improved creative thinking 
skills as one of the goals of early childhood learning and basic education (Widiana, Bayu, \& Jayanta, 2017; Widiana \& Jampel, 2016).

These findings have implications for the policy of developing early childhood instructional media. These implications include the use of cognitive learning objectives at various levels for the application and implementation of early childhood education. The use of early childhood education media by using Anderson and Kratwohl cognitive goals make it easier for teachers to conduct assessments. In addition, the results of this development research can be a reference for teachers in developing media for children, especially for the development of cognitive aspects.

\section{Conclusion}

Cognitive aspects in early childhood education include aspects of learning and problem solving, logical thinking, and symbolic thinking. The three aspects are arranged into instructional media consisting of annual programs, semester programs, weekly lesson plans, and daily lesson plans. Product validations are based on expert test results. Material expert assessed the products that are developed in the excellent category. The results of the instructional design expert validation to the products developed results in excellent category. While the teacher's perception of the instructional media developed is in the very good category.

\section{References}

Anderson, L. W., \& Krathwohl, D. R. (2001). A taxonomy for learning, teaching, and assessing. New York: Addison Wesley Longman.

Arends, R. I. (2013). Learning how to teach (9 ${ }^{\text {th }}$ Ed). Boston: McGraw Hill.

Bergen, D. (2018). Cognitive development in play-based learning. Encyclopedia on Early Childhood Development, 1-4.

Bransford, J. D., Brown, A. L., \& Cocking, R. R. (2000). How people learn: Brain, mind, experience, and school. Washington: National Academy Press.

Carson, V., Hunter, S., Kuzik, N., Wiebe, S.A., Spence, J.C., Friedman, A., Tremblay, M.S., Slater, L., \& Hinkley, T. (2015). Systematic review of physical activity and cognitive development in early childhood. Journal of Science and Medicine in Sport, 1-7

Effendi, R. (2017). Konsep revisi taksonomi Bloom dan implementasinya pada pelajaran matematika SMP. Jurnal IImiah Pendidikan Matematika, 2 (1), 72-78.

Filtri, H., \& Sembiring, A.K. (2018). Perkembangan kognitif anak usia 5-6 tahun di tinjau dari tingkat pendidikan ibu di PAUD kasih ibu kecamatan rumbai, PAUD Lectura: Jurnal Pendidikan Anak Usia Dini, 1(2), 169-178.

Hoque, M. E. (2017). Three domain of learning: Cognitive, affective, and psychomotor. The Journal of EFL Education and Research, 2(2), 45-52.

Kementerian Pendidikan dan Kebudayaan (Kemendikbud). (2014). Peraturan menteri pendidikan dan kebudayaan nomor 137 tahun 2014 tentang standar nasional pendidikan anak usia dini. Jakarta: Kemendikbud.

Kementerian Pendidikan dan Kebudayaan (Kemendikbud). (2014). Peraturan menteri pendidikan dan kebudayaan nomor 146 tahun 2014 tentang kurikulum 2013 pendidikan anak usia dini. Jakarta: Kemendikbud.

Krogh, S. L., \& Morehouase, P. (2014). The early childhood curriculum: Inquiry learning through integration. Washington: Routledge.

Krogh, S. L., \& Slentz, K. L. (2010). Early childhood education: Yesterday, today, and tomorrow. Washington: Taylor \& Francis.

Laksana, D. N. L. (2017). The effectiveness of inquiry based learning for natural science learning in elementary school. Journal of Education Technology. 1(1), 1-5.

Muga, W., Oje, M.S., \& Laksana, D.N.L. (2018). Hasil belajar kognitif siswa SD dalam pembelajaran kontekstual media mazi (studi pada siswa SD kelas tinggi). Journal of Education Technology, 2(1), 20-25.

Novitasari, Y. (2018). Analisis permasalahan perkembangan kognitif anak usia dini. PAUD Lectura: Jurnal Pendidikan Anak Usia Dini, 2(1), 82-90. 
Pancaningrum, N. (2016). Strategi pembelajaran: Taksonomi bloom dalam games simulation method di tingkat raudhatul athfal. Jurnal Inovasi Pendidikan Guru Raudhatul Athfal, 4(1), 112-129.

Pertiwi, N. L. S. A., Arini, N. W., \& Widiana, I. W., (2016). Analisis tes formatif bahasa Indonesia kelas IV ditinjau dari taksonomi Bloom revisi. e-Journal PGSD Universitas Pendidikan Ganesha, 4(1), 1-11.

Piaget, J., \& Inhelder, B. (2019). The psychology of the child. New York: Basic Books.

Rohmah, N., \& Waluyo, E. (2014). Arithmetic dice media as counting concept introduction media in early childhood setting. Indonesian Journal of Early Childhood Education Studies, 3(2), 127-133.

Sarjono. (2016). Pengembangan soal fisika SMA/MA Politomus Berbasis Taksonomi Bloom Revisi. Jurnal Madaniyah, 1(10), 1-16.

Selmi, A. M., Gallagher, R. J., \& Mora-Flores, E. R. (2014). Early childhood curriculum for all learner: Integrating play and literacy activities. New York: Sage Publications.

Tomar, R., \& Kumari, A. (2017). Cognitive development of children in private franchise preschool. International Journal of Recent Scientific Research, 8(2), 15494-15499

Undang-undang Republik Indonesia Nomor 20 Tahun 2003 tentang Sistem Pendidikan Nasional.

Wahyuni, S. (2017). Development test system based on linear equations two variable revised taxonomy Bloom to measure high order thinking skills at student class VIII SMPN Sungguminasa Gowa. Jurnal Daya Matematis, 5(1), 129-152

Webb, D.L., Metha, A., \& Jordan, K.F. (2010). Foundations of American Education, $6^{\text {th }}$ Ed. New Jersey: Merill.

Widiana, I. W., \& Jampel, I. N. (2016). Improving students' creative thinking and achievement through the implementation of multiple intelligence approach with mind mapping. International Journal of Evaluation and Research in Education, 5(3), 246-254.

Widiana, I. W., Bayu, G. W., \& Jayanta, I. N. L. (2017). Pembelajaran berbasis otak (brain based learning), gaya kognitif kemampuan berpikir kreatif dan hasil belajar mahasiswa. Jurnal Pendidikan Indonesia, 6(1), 1-15.

Winarni, D.S. (2017). Analisis kesulitan guru PAUD dalam membelajarakan IPA pada anak usia dini. EduSains: Jurnal Pendidikan Sains \& Matematika, 5(1), 12-22.

Zeng, N., Ayyub, M., Sun, H., Wen, X., Xiang, P., \& Gao, Z. (2017). Effects of physical activity on motor skills and cognitive development in early childhood: A systematic review. BioMed Research International, 1-13. 